\title{
Seeking a Better Experimental Model of Atrial Fibrillation
}

\author{
Kensuke Ihara, MD, PhD; Tetsuo Sasano, MD, PhD
}

$\mathbf{R}$ hythm control therapy for paroxysmal atrial fibrillation (AF) has extensively advanced in the past couple of decades by catheter ablation (CA) for pulmonary vein isolation. ${ }^{1}$ However, the success rate of $\mathrm{CA}$ for persistent $\mathrm{AF}$ is still limited, even with an additional ablation strategy. ${ }^{2}$ The obstacle to the treatment of persistent $\mathrm{AF}$ is the accumulation of AF substrate in the atria. The AF substrate has electrical aspects due to changes in ion channel expression and function, and structural aspects based on inflammation, fibrosis, and apoptosis in atrial tissue. To improve therapeutic strategies for persistent AF, it is necessary to clarify the relationship between the AF substrate and arrhythmogenicity. As an example, rotor activity is considered one of the critical mechanisms for the maintenance of $\mathrm{AF} ;{ }^{3}$ however, the contribution of the $\mathrm{AF}$ substrate to generate the rotor remains unclear. Therefore, a more detailed understanding of the characterization of the AF substrate is needed using experimental models.

In this issue of the Journal, Horii et al reported that laser irradiation on the atrial surface could create a substrate of atrial arrhythmia using murine perfused heart. ${ }^{4}$ The authors developed a retrograde perfusion method that avoids mechanical damage to the atria, and established a laser irradiation system that controls the shape of the injured area. They found that the circular-shaped lesion was unable to induce atrial arrhythmogenicity; however, the wedge-shaped lesion successfully induced long, persistent atrial tachycardia in a

\begin{abstract}
Article p????
murine heart, although fine AF could not be induced. They also showed that the irradiated area had a reduced content of nicotinamide adenine dinucleotide, which contributed to the substrate of atrial tachycardia.

Currently, several experimental subjects are used in cardiac electrophysiological analysis: (1) single cardiomyocyte; (2) cell sheet; (3) cardiac organoids; (4) section of the heart; (5) whole heart; and (6) computational simulation model (Table). Single cells include cultured cells, primary cardiomyocytes, cardiomyocytes derived from embryonic stem cells or induced pluripotent stem cells, and are mainly analyzed with the patch clamp technique.,56 These cells are also used for the generation of a cell sheet for the analysis of intercellular conduction and propagation. The cell sheet has a 2-dimensional structure and is assessed with optical mapping or multi-electrode array. ${ }^{7}$ Cell-to-cell conduction can also be assessed using a dual whole-cell patch clamp with coupled cells. The generation of cardiac organoids is recently established, and several studies reported that it showed atrial and ventricular electrophysiological properties. ${ }^{8,9}$ In contrast to a cell sheet, the cardiac organoid has the potential to be analyzed in a 3-dimensional model and is useful for the investigation of arrhythmias.
\end{abstract}

To analyze the electrical behavior and mechanism of

\begin{tabular}{|c|c|c|c|}
\hline Subject & $\begin{array}{l}\text { Arrhythmia } \\
\text { induction }\end{array}$ & $\begin{array}{l}\text { Assessment } \\
\text { method }\end{array}$ & Note \\
\hline Cell & Impossible & $\begin{array}{l}\text { Patch clamp } \\
\text { Optical mapping }\end{array}$ & $\begin{array}{l}\text { It enables the clarification of the function of the ion channel. The } \\
\text { dual whole cell patch clamp can assess cell-to-cell conduction. }\end{array}$ \\
\hline Cell sheet & Possible & $\begin{array}{l}\text { Multi-electrode array } \\
\text { Optical mapping }\end{array}$ & $\begin{array}{l}\text { Most of the experimental system is produced to assess a } \\
\text { 2-dimensional model. }\end{array}$ \\
\hline Organoid & Possible & Optical mapping & $\begin{array}{l}\text { This is a promising experimental subject for 3-dimensional } \\
\text { analysis, but it still needs to be well-established. }\end{array}$ \\
\hline Section of the heart & Possible & $\begin{array}{l}\text { Electrocardiogram } \\
\text { Local electrogram } \\
\text { Optical mapping }\end{array}$ & $\begin{array}{l}\text { Isolated atrial tissue can be used to assess the electrophysiological } \\
\text { properties of the atrium. }\end{array}$ \\
\hline Whole heart & Possible & $\begin{array}{l}\text { Electrocardiogram } \\
\text { Local electrogram } \\
\text { Optical mapping }\end{array}$ & $\begin{array}{l}\text { Generally, it is difficult to induce arrhythmias in the small animal } \\
\text { heart. }\end{array}$ \\
\hline
\end{tabular}

The opinions expressed in this article are not necessarily those of the editors or of the Japanese Circulation Society.

Received August 31, 2021; accepted August 31, 2021; J-STAGE Advance Publication released online October 9, 2021

Department of Bio-informational Pharmacology, Medical Research Institute (K.I.), Department of Cardiovascular Medicine (K.I.,

T.S.), Tokyo Medical and Dental University (TMDU), Tokyo, Japan

Mailing address: Tetsuo Sasano, MD, PhD, Department of Cardiovascular Medicine, Tokyo Medical and Dental University

(TMDU), 1-5-45 Yushima, Bunkyo-ku, Tokyo 113-8519, Japan. E-mail: sasano.cvm@tmd.ac.jp

All rights are reserved to the Japanese Circulation Society. For permissions, please e-mail: cj@j-circ.or.jp

ISSN-1346-9843 
cardiac arrhythmias, especially complex arrhythmias such as $\mathrm{AF}$, the best way is to use the actual heart. Various mammalian hearts, including the human heart, which is obtained during heart transplantation, large animal hearts (horses, goats, pigs, dogs, etc.), and small animal hearts (rabbits and rodents) have been used for the basic research of arrhythmias. In large animals, chronic rapid atrial pacing is commonly performed for the induction of AF.10 Moreover, it is possible to observe spontaneous AF in some healthy large animals. ${ }^{11}$ The large animal heart can be evaluated with the same electrophysiological study equipment used clinically.

Because of its ease of accessibility, handling, and genetic modification, the murine heart has been studied for cardiac arrhythmias. However, the mouse heart has difficulty in the inducibility of arrhythmias, especially atrial arrhythmias including AF, due to its small size. Several studies reported the inducibility of sustained atrial tachyarrhythmia in the transverse aortic constriction model, ${ }^{\mathbf{1 2}}$ and spontaneous AF in genetically modified mouse strains. ${ }^{13,14} \mathrm{~A}$ high-resolution optical mapping enables a detailed assessment of propagation. However, there is no established method with a high success rate in inducing sustained atrial arrhythmia in wild-type murine hearts. In this regard, the report by Horii et $\mathrm{al}^{4}$ provides a novel approach to induce atrial arrhythmia in the murine heart by artificial generation of the AF substrate by laser irradiation. This is a major step forward in the basic research on $\mathrm{AF}$, and future developments are highly anticipated.

\section{Disclosures}

The authors have no conflicts of interest to declare.

\section{References}

1. Haissaguerre M, Jais P, Shah DC, Takahashi A, Hocini M, Quiniou G, et al. Spontaneous initiation of atrial fibrillation by ectopic beats originating in the pulmonary veins. $N$ Engl J Med 1998; 339: 659-666.
2. Verma A, Jiang CY, Betts TR, Chen J, Deisenhofer I, Mantovan $\mathrm{R}$, et al. Approaches to catheter ablation for persistent atrial fibrillation. N Engl J Med 2015; 372: 1812-1822.

3. Narayan SM, Baykaner T, Clopton P, Schricker A, Lalani GG, Krummen DE, et al. Ablation of rotor and focal sources reduces late recurrence of atrial fibrillation compared with trigger ablation alone: Extended follow-up of the CONFIRM Trial (Conventional Ablation for Atrial Fibrillation With or Without Focal Impulse and Rotor Modulation). J Am Coll Cardiol 2014; 63: 1761-1768.

4. Horii S, Yada H, Ito K, Tsujita K, Osaki A, Kagami K, et al. Artificially created reentry circuit by laser irradiation causes atrial tachycardia to persist in murine atria. Circ J, doi:10.1253/ circj.CJ-20-1286.

5. Ehrlich JR, Cha TJ, Zhang L, Chartier D, Melnyk P, Hohnloser $\mathrm{SH}$, et al. Cellular electrophysiology of canine pulmonary vein cardiomyocytes: Action potential and ionic current properties. $J$ Physiol 2003; 551: 801-813.

6. Ma J, Guo L, Fiene SJ, Anson BD, Thomson JA, Kamp TJ, et al. High purity human-induced pluripotent stem cell-derived cardiomyocytes: Electrophysiological properties of action potentials and ionic currents. Am J Physiol Heart Circ Physiol 2011; 301: $\mathrm{H} 2006-\mathrm{H} 2017$.

7. Herron TJ, Lee P, Jalife J. Optical imaging of voltage and calcium in cardiac cells \& tissues. Circ Res 2012; 110: 609-623.

8. Lee J, Sutani A, Kaneko R, Takeuchi J, Sasano T, Kohda T, et al. In vitro generation of functional murine heart organoids via FGF4 and extracellular matrix. Nat Commun 2020; 11: 4283.

9. Goldfracht I, Protze S, Shiti A, Setter N, Gruber A, Shaheen N, et al. Generating ring-shaped engineered heart tissues from ventricular and atrial human pluripotent stem cell-derived cardiomyocytes. Nat Commun 2020; 11: 75.

10. Wijffels MCEF, Kirchhof CJHJ, Dorland R, Allessie MA. Atrial fibrillation begets atrial fibrillation: A study in awake chronically instrumented goats. Circulation 1995; 92: 1954-1968.

11. Saljic A, Jespersen T, Buhl R. Anti-arrhythmic investigations in large animal models of atrial fibrillation. $\mathrm{Br} J$ Pharmacol, doi:10.1111/bph.15417.

12. Ihara K, Sugiyama K, Takahashi K, Yamazoe M, Sasano T, Furukawa T. Electrophysiological assessment of murine atria with high-resolution optical mapping. J Vis Exp 2018; (132): 56478.

13. Riley G, Syeda F, Kirchhof P, Fabritz L. An introduction to murine models of atrial fibrillation. Front Physiol 2012; 3: 296.

14. Ihara K, Sasano T, Hiraoka Y, Togo-Ohno M, Soejima Y, Sawabe $\mathrm{M}$, et al. A missense mutation in the RSRSP stretch of Rbm20 causes dilated cardiomyopathy and atrial fibrillation in mice. Sci Rep 2020; 10: 17894. 